\title{
10
}

\section{The Legal Framework for Private Sector Activities in Turkey}

\author{
Tuğrul Arat, Izak Atiyas, Erdem Başçı and Turgut Tan
}

The purpose of this chapter is to review the basic components of the legal framework for private sector activities in Turkey. The chapter is organised as follows. Section 10.1 is on property rights. Section 10.2 studies contract law and Section 10.3 company law and bankruptcy law. Section 10.4 discusses competition policy, regulation in the context of competition law, state procurement, private participation in infrastructure and price regulation. Section 10.5 discusses privatisation efforts in Turkey and Section 10.6 summarises the conclusions.

\subsection{Property rights}

A necessary condition for the presence of a market economy is the existence of a suitable property rights structure. ${ }^{1}$ In any economy the property rights structure is a mix of private, public (status) and communal rights. ${ }^{2}$ Here, public (status) rights are those rights that can be used by administrators due to their public officer status and communal rights are the rights of private individuals over public (common) property. ${ }^{3}$ To study the characteristics of a private property system we consider the following four questions. What can be privately owned? How are ownership rights established? What may owners legitimately do with their property? How are property rights protected and what are the remedies for their infringement?'4

The first question is concerned with the issue of private versus public ownership of real property. During the Ottoman period, private ownership of land and real property existed mainly in the urban areas. However, most agricultural land was subject to the public land (miri arazi) regime, whereby, the land was owned by the state and the state allocated the right to use the land to farmers. The right to tax the farmers on behalf of the state was vested in timar holders (tax farmers) at tax rates fixed by the state. After the gradual deterioration of the timar system from the second half of sixteenth century, timar holders began to act as though they owned the land allocated to them. But legally the land was still the property of the state, which gave up this right only in 1926 when the Republic of Turkey adopted a new civil code. According 
to this code, any Turkish citizen who could prove to the court that he or she had been cultivating a piece of land for at least last ten years was given the title deeds. At that time a new land registry system was established ${ }^{5}$ and the land registration procedure has continued ever since. By 1993 around 68 per cent of the land had been registered and by 2000 all of the land is expected to be registered. ${ }^{6}$

Land reform has been on the agenda for a very long time. The constitution of 1982 requires the state to provide poor farmers with land. ${ }^{7}$ However, reforms have not been implemented despite the acceptance of the law on Agricultural and Land Reform in 1975. The issue has been mostly off the agenda since the 1980s. A less radical law limited mostly to the south-eastern Anatolia irrigation project, was passed in $1984 .^{8}$

The ownership of natural wealth and resources, concepts whose precise definitions are absent from the constitution, is vested in the state by Article 168 , which also allows for the right to use these resources to be delegated to private agents for a limited time. ${ }^{9}$ Coasts, lake shores, river-banks and forests are under the control of the state. ${ }^{10}$

Regarding the question of how ownership rights were established, the civil code of 1926, adopted from Switzerland, introduced new arrangements for inheritance and other means of acquising property. No significant amendments have been made to these rules since then, and the code is in conformity with those in force in contemporary market economies.

With regard to what owners can legitimately do with their property, property can be seen as a bundle of rights to use, transform, pledge, transfer (sell), bequeath, receive income generated from and exclude others from use. The legal arrangements relating to these seven rights are supposed to facilitate the efficient use of resources. Not all of the rights were granted to private economic agents in the Ottoman period. Under the tımar system the state had absolute possession of the land (rakabe), but in practice the State handed the right to receive income from the land in the form of taxes to timar holders, and the right to use the land for productive activities was given to farmers. Neither the timar holders nor the farmers could rent, transfer, pledge or bequeath the land. The right to transform the land was also restricted. All of these rights were transferred to the owner by the 1926 Civil Code.

In 1989, the Turkish Constitutional Court defined the right to real property, but very vaguely. The phrase 'within the limits of the permission granted by the State' leaves so much discretion to the state that it can virtually wipe out all conceivable property rights. ${ }^{11}$ In the Turkish civil code and in practice the seven rights mentioned above are protected by both law and social norms. In the specific case of real property there are still some restrictions on some of these rights. For instance, in the house rental market a tenant cannot be easily evicted by the owner of the house after the expiration of the contract in order to rent the house to some other party. A valid ground for eviction is the proven need for its use by the owner or all close relative. ${ }^{12}$ 
Finally, regarding the last question, protection by law of property rights against acts of others or the state is needed due to the problem of nonseparability of property rights and the resulting externalities. The Turkish constitution restricts discretionary expropriations and similar threats to private property by the state by requiring that such acts be executed in compliance with objective conditions foreseen by law, ${ }^{13}$ and requiring compensation to be paid based on 'objective criteria'.$^{14}$ Of course, estimating the private value is very difficult and in the case of the private value exceeding the objective value the private agent could loose out. But this seems an unavoidable problem that is also present in well-established market economies. In such cases, legal protection is available, and there are various examples indicating that the courts can either avoid or reduce the damages to private citizens.

The Turkish constitution provides for the nationalisation of enterprises in Article $47,{ }^{15}$ although privatisation is not mentioned per se. Hence in appeals to the Constitutional Court, Article 47 is interpreted as 'privatisation will be at real value' and a law is required to describe the procedures for determining that value.

The protection of private property from private intrusion is quite strong in Turkey. In the case of real property, ownership cannot be seized by a second party if the land has been registered. If the land is not registered, for claims possession by other parties can be made after 20 years of proven uninterrupted use. Protection of private property from use by second parties is also quite strong. Firstly, the local administration has the power to hand an injunction to an illegal user of land upon application by the injured party, but the former party may take the case to court in case of dispute. Secondly, monetary compensation may be sought by the injured party in the courts.

The next question is what the state and state enterprises can do with their real property. Private and public properties are subject to different legislation. In accordance with the constitution, the Turkish civil code states that 'unowned places' (land unsuitable for cuitivation, barren land, mountains, springs, seas, lakes and so on) and 'real property of public interest' (devoted to common public use such as roads, parks, and so on) are at the state's disposal and special provisions are made for their exploitation and use (Articles 641 and 912). The Cadastre Law, in defining state-owned property, provides for a third property group, namely 'places which are set apart for public services and which are actually used' (Article 16). This third group is called 'service property' to which the administration's rights are recognised. Properties allocated to public services are subject to the public services provisions of administrative law, not to the provisions of private law. ${ }^{16}$ As a result of this discrimination between properties owned by the administration, those that are not allocated for public services and those that are not actually used in public services, may be sold or hired by the administration and the properties 
administration may benefit from their revenues by establishing right of servitude and usufruct. Such properties are called 'private possessions' and the administration is recognised as having the same rights and authority over them that the civil code established for the owners. However, in exercising these rights the administration must comply with certain measure arising from administrative law, especially General Accounting Law 1050 and Public Procurement Law 2886.

State-owned properties are subject to special protection by law. There are special provisions in Turkish criminal code ${ }^{17}$ the Law on Protecting Real Property (Law 3091) and the Law on Protecting Natural and Cultural Wealth (Law 2863). State-owned properties can not be acquired through extraordinary prescription ${ }^{18}$ and cannot be attached. ${ }^{19}$ According to Constitutional Court this provision aims at 'allowing public services to be provided systematically and continuously'. ${ }^{20}$ Crimes committed against the property or assets of enterprises, institutions and joint ventures are treated as being committed against public property, and the 'movable and immovable property of the enterprises can not be attached'. ${ }^{21}$ The prohibition against attachment was abolished under Law 4011, enacted in 1994. In the same year, Article 15 of Law 4046 placed the same prohibition on organisations that were included or were to be included in the privatisation programme. This article has since been annulled by the Constitutional Court.

Regarding the protection of intellectual, industrial and commercial property rights, Turkey delayed recognition of these rights for a very long time. According to the 6 March, 1995 decision of the EC-Turkey Association Council, the customs union can function properly only if there is effective protection of intellectual property rights in Turkey (Article 31). Accordingly Turkey has undertaken to meet the obligations set out in Annex 8 of the decision (this is discussed in some detail in chapter 2 of this volume).

\subsection{Contract law}

A significant question to be answered in the field of contract law is whether all contracts should be enforced by the courts. According to classical or bargaining theory ${ }^{22}$ a contract should be enforced if and only if it is signed as part of a bargain. In the event of breach of contract the remedy should be equal to the expected damages. There are also arguments for the enforcement of one-sided offers ${ }^{23}$ (promises), such as quoting a sales price, gift promises and so on. But classical contract theory is valid under very restrictive assumptions, full rationality among all agents, completed contracts and perfectly competitive markets. Under these conditions contracts should be strictly enforced according to their terms. Otherwise the contract is called imperfect and it may not be desirable fully to enforce it. A complete contract is one in which all possible future contingencies are covered. Obviously this is a practical impossibility even if all the agents are 
rational due to the prohibitively high transaction costs of identifying, specifying and bargaining over all possible contingencies. Therefore, classical contract theory is not applicable in real life and contracts will not always be enforced according to their terms. If the court disputes an incomplete contract due to a contingency that, say, makes the contract impossible to fulfill, the court should try to restructure the terms of the contract in such a way that the parties would have wanted ex ante. ${ }^{24}$ This theoretical principle is not easy to understand and apply in practice, so some rules of thumb have been developed. One such rule is that the party that could, at a lower cost, avoid or insure against the contigency is held liable. ${ }^{25}$ Another rule comes under the title 'protection of the economically weak', which in most cases agrees with the previous rule in its prescriptions.

Freedom of contract is sanctioned in the Turkish constitution. ${ }^{26}$ The relevant legal provisions are mainly laid down in the Code of Obligations, dating back to 1926, which was adopted from the Swiss Code of Obligations. No significant changes have taken place since then. The Code of Obligations (article 19 and 20) provides freedom of contract within a flexible framework that may be restricted by limitations imposed by the general principles of law, considerations of public order, and prohibition of immorality acts (article $19 /$ II). Furthermore, no person can renounce all or part of his capacity to have rights and to enter into legal transactions. Finally, if the performance of the subject matter of the contract is impossible prior to the making of the contract, such contracts are void.

The classical view is not taken, and the courts usually apply the rule of 'protection of the economically weak' in forming their opinion when the related law allows them to do so. This may promote efficiency in some cases of 'impossibility', but in other cases it may reduce efficiency. The housing rental market is a good example in this regard. This market and the labour market are regarded as 'different' by Turkish law. ${ }^{27}$ Therefore, measures to protect the economically weak are taken. For instance even if the contract specifies a rent rise equal to or above the inflation rate, the court will usually not enforce it and will decide on a rise that is below the inflation rate. This, however, is gradually changing and even contracts indexed to US dollars have started to be signed and enforced.

In order to protect less informed and economically weak, consumers from arbitrary actions by monopolies, such firms are required to enter into contract with their clients. ${ }^{28}$ This also applies to state-owned public utilities (electricity, gas, telephone and so on).

A remarkable limitation on freedom of contract in corporation law is that commercial companies must operate in the area of business specified in their articles of incorporation as laid down in the Commercial Code (Article 137). Therefore, transactions in fields other than those specified in the articles of incorportion are not binding on the corporation. This matter is overcome by firms expanding the stated objectives of the corporation as much as possible. 
The administration can enter into two types of contract. Private law contracts are issued by the administration in accordance with private law and any disputes that arise are resolved in the courts of general jurisdiction. Administrative contracts are subject to administrative law and disputes are resolved in the administrative courts. For instance,contracts entered into by the administration for purchasing, sales, leasing and so on in accordance with State Bidding Law 2886 are considered as private law contracts. Similarly,contracts signed between organisations providing public services of an economic character (electricity, telephone, gas and so on) and those who benefit from these services, as well as so-called 'subscription contracts' are considered as private law contracts. Since the provisions of these types of contract are unilaterally specified by the administration and the beneficiaries accept them, they are also called 'adhesive contracts' (contract d'adhesion). As will be discussed below, contracts concluded with private companies to provide certain public services and so-called 'build-operatetransfer' contracts have caused serious legal difficulties.

A guarantee contract, in its broadest sense, is a contract through which the risks are fully allocated to one of the parties. Certain types of guarantee contract have been regarded as special by Turkish law. Two examples are surety contracts $^{29}$ and insurance contracts. ${ }^{30}$ There are also contracts not regulated by law, such as letters of credit by banks. Such contracts are acknowledged by the courts in line with international practices. Contracts bearing an obligation of immovable pledge are regulated by the civil code, ${ }^{31}$ while the Law on Commercial Enterprise Pledge 1447 allows a debtor firm to return the movable pledge. Among guarantee contracts, those that contain pledge and mortgage obligations on movable, immovable, credit or operation aim at providing the creditor with security. In the event of this pledge being given by the debtor himself, the creditor has the right to collect his claim on the pledged property as a first priority, and on other attachable commodities together with other creditors. In the case of a personal guarantee, a creditor obtaining such a guarantee may collect his claim from the property of the primary debtor as well as the property of the guarantee debtor.

In practice, there is a widespread understanding and use of contracts in commerce, the labour market, the housing market and money and credit markets. In the case of commercial contracts, equality and bargaining principles are emphasised by the courts, and hence formally valid contracts are almost always enforced according to their terms. For the principle of 'protection of the weak' to be taken into account, the courts seek guidance from related law. For example, there is special legislation for the labour and housing markets that tends to distort the operation of free market prices. Such arrangements also exist in many European countries, such as France. The main problems with contract enforcement in Turkey arise from overload, and the resulting slow operation of the courts, ${ }^{32}$ and from the remedies being inadequate to the needs of the business community. 


\subsection{Company and bankruptcy law}

The purpose of company law can be defined as facilitating production by reducing the various transaction and agency costs that arise between different stakeholders. ${ }^{33}$ The literature especially emphasises the agency costs that may arise from conflicts of interest among the owners (partners), between the owners (or shareholders) and managers, between majority and minority shareholders, and between owners/managers and creditors.

Freedom to establish a private enterprise is guaranteed by the constitution. ${ }^{34}$ Company law is part of the Commercial Code, which came into force in 1957. According to the code, companies are classified as general partnerships (unlimited companies), limited partnerships, joint stock companies, limited liability companies or cooperatives (Article 136). Turkish legislation seems to force certain types of commercial activity to be carried out by joint stock companies. For instance, according to Law 4046, enterprises awaiting privatisation must be transformed into joint stock companies (Article 37), and it is deemed by the Law on the Realisation of Certain Investment and Services within the Build-Operate-Transfer Model that a 'capital company' that intends to provide services must be a joint stock company with certain requisites. Similarly, companies to be set up in the banking sector (Bank Law, Article 5), the insurance sector (Insurance Supervision Law, Article 2), private radio and television (Law 3984, Article 29) and finance and factoring partnerships (Decree Law 3984, Article 29) are required to take the form of a joint stock company. By contrast, joint ventures that involve the exchange of technical know-how, financial and commercial knowledge, and international transfer of technology, especially for the construction of bridges, dams, tunnels and so on, are not separately regulated by Turkish legislation. Rather they are treated as ordinary partnerships and are thus subject to the Code of Obligations (Article 520). The Corporate Tax Law, temporary Article 6, treats joint ventures in the same way as corporations. Similarly a consortium is constreated as an ordinary partnership.

Joint stock companies are widespread and have gained importance since the enactment of the Capital Market Law. Joint stock companies may be established for all economic purposes except those forbidden by law. The legal minimum number of founding members is five and start-up capital must not be not less than TL5 billion, unless stated otherwise in a special law. The requirements for the establishment of a joint stock corporation are articles of incorporation, permission from the Ministry of Industry and Commerce, and registration in the commercial registry. Any amendments to the charter are subject to the permission of the Ministry of Industry and Commerce (Decree by the Ministry of Industry and Commerce on the Establishment of and Amendments to the Charters of Joint Stock Corporations and Limited Liability Companies, 1995).

Joint stock companies issue shares. Shares are securities - that is, in a broad sense, a capital market instrument. Joint stock companies may also issue 
redeemable shares and bonds. Such companies may be dissolved for a number reasons (Commercial Code, Articles 434-7), and when dissolved are subject to liquidation (Commercial Code, Article 439). Once liquidated their trade names are removed from the commercial registry upon the request of the liquidators. In the case of bankruptcy, the company is liquidated by the bankruptcy trustee in accordance with the provisions of the Execution and Bankruptcy Law (Articles 179, 200, 208, 223). Article 274 of the Commercial Code, amended by Decree Law 559, decrees that joint stock companies must be supervised by commercial inspectors from the Ministry of Industry and Commerce, which may file for the dissolution of companies that violate the law, diverge from the company articles of incorporation, or disturb the public order.

The Capital Market Law, amended by Decree Law 558, introduced new provisions. Any amendment to a company charter became subject to the permission of the Capital Market Board. The board was empowered to take legal action against a company to terminate any of the company's activities and operations that did not comply with the law, the company articles of incorporation or the purpose and principles of the establishment, or which might lead to the reduction or loss of operating capital or resources. The board could order companies to comply with the legislation and could assign nonvoting representatives to participate in the company's general assembly to inform stockholders and to warn the administrative and supervisory bodies, where necessary. Decree Law 558 was annulled by the Constitutional Court on the ground that the law upon which it was based (Authorization Law 4113) had been annulled (Decision E. 995/45. K. 995/58 of 13 November, 1995).

As in many other countries, there are specific provisions on joint stock companies in the Commercial Code that can be seen as attempting to address the interests the parties. The fiduciary responsibilities of managers are clearly stated in Article 342. Self-interested transactions are constrained by the requirement that any transaction between a member of the board of directors and the company must be subject to shareholder approval ${ }^{35}$ (Article 334). The protection of minority shareholders is also catered for. Minority shareholders holding 10 per cent of total shares have the right to take the board of directors to court (Article 341), place items on the agendas of shareholder meetings, call extraordinary meetings of shareholders (Article 366), appoint special auditors (Article 348) and file complaints with regular company auditors appointed by the general assembly (Article 356). ${ }^{36}$ The board of directors is also held responsible for informing the general assembly of shareholders of any deterioration of the financial position of the company. However the 'early warning' quality of this provision is limited since the board is required to act only if the last annual balance sheet shows that the company's capital has been depleted by 50 per cent (Article 324). Dividends can be paid only after the required additions to the capital reserves from net profits have been made (Article 469). 
Traders are subject to bankruptcy (Execution and Bankruptcy Law, Article 43). However certain non-traders are subject to bankruptcy as well. For example a former trader may be acted against for up to one year after leaving the trade (Execution and Bankruptcy Law, Article 44), and the shareholders of a limited liability or joint stock company are subject to bankruptcy under certain conditions (Commercial Law, Articles 180, 182, 256), even though they are not considered to be traders.

Turkish legislation defines three forms of bankruptcy: general bankruptcy (Execution and Bankruptcy Law, Articles 155-6), bankruptcy related to exchange bills (cheque, bills of exchange, bonds: Execution and Bankruptcy Law, Articles 167, 171-6) and direct bankruptcy (that is, going directly to the commercial court without first applying to the enforcement office: Execution and Bankruptcy Law, Articles 177-81). There also exist laws in which bankruptcy is arranged in special ways, for example the Banking Law regulates bank insolvency.

In principle banks are considered as traders and are therefore subject to bankruptcy. In the event of a bank's assets failing to cover its liabilities, the board of directors must apply to the Commercial Court for bankruptcy proceeding (Execution and Bankruptcy Law, Article 179 and Commercial Code, Article 324). A creditor of a bank may also lodge a request with the Commercial Court that the bank be declared bankrupt (Execution and Bankruptcy Law, Article 179). Finally, according to the Banking Law a savings deposit insurance fund can apply for bankruptcy proceedings to be taken against a bank on behalf of its depositors.

The most common result of bankruptcy is liquidation. This is partly due to the fact that by the time a petition for bankruptcy occurs, the financial position of the debtor has often seriously deteriorated, perhaps reflecting the absence of preventive mechanisms that characterise some of the current European bankruptcy laws. ${ }^{37}$ However the law does allow for reorganisation via a concordat between the debtor firm and its creditors. Concordats are often used to provide a breathing space to debtors, who normally remain in possession and continue to manage the company until an agreement is reached.

\subsection{Competition policy and regulation}

\section{Competition law}

A significant step in the area of competition policy was taken with the enactment of Law 4054 on protection of competition in December 1994. As described in detail in Chapter 12 of this volume, the law deems illegal and therefore prohibits all activities and decisions of enterprises that directly or indirectly prevent, distort or restrict competition (Article 4); the abuse of a dominant position in the goods and services markets (Article 6); and mergers 
and acquisitions resulting in a dominant and strengthened position. The law also provided for the establishment of a Competition Authority to implement the law. ${ }^{38}$

The Competition Board was eventually established after a delay of more than two years (Council of Ministers decision 97/9090). The board has the important task of educating the public as to what competition policy means and how it should be conducted. A competitive code of conduct is an alien concept to the majority of businesses and industries. Public opinion, on the other hand, is likely to see competition policy as a tool to protect the weak against the powerful, that is, as a primarily redistributive tool. ${ }^{39}$ Significant effort will have to be made to explain the efficiency objectives of competition policy. ${ }^{40}$

\section{State procurement and the regulation of private participation in infrastructural projects}

The state is a significant purchaser of goods and services. The share of the public sector in Turkey's fixed capital investment is about 40 per cent. For instance the state invested TL9.3 trillion in the energy and transportation sectors in 1993, which represents nearly 30 per cent of overall investment in Turkey that year.

Rules governing the procurement of goods and services should strive to maintain a level playing field, transparency and competition. In Turkey the procedures followed in public procurement are specified in State Bidding Law 2886 , and in certain special legal and administrative regulations. There are several important problems with the current procurement system. An abundant number of public establishments are not covered by Law 2886. In addition Law 2886 recognises many exceptions. Purchases made through sealed tenders or bargaining are not required to be declared. The government has too much discretionary power, for example in cases where foreign bids are invited the Council of Ministers is authorised to determine the degree to which domestic bidders will be favoured. The fact that bid results are not required to be announced, and that rejected bidders are not required to be informed, does little to improve transparency. A new draft is being prepared to address these problems.

In the 1980s several laws were introduced to allow domestic and foreign firms to provide certain public services. The first was Law 3096 of 1984, which allowed domestic and foreign capital companies, subject to the provisions of private law (joint stock corporations), to produce, transmit and distribute electricity. This was followed by Law 3465 of 1988 to allow capital companies, subject to the provisions of private law, to build, maintain and operate highways, and related facilities on highways. Finally, Law 3996 of 1994 permitted domestic capital companies and foreign companies to build and operate bridges, tunnels, dams, irrigation projects, drinking water supplies and water-purifying units, sewerage, communication units, highways, railways 
and parking lots within the framework of the 'build-operate-transfer' (BOT) model.

The BOT model has faced serious legal difficulties. The provisions of Law 3096 (amended by Law 3974) and Law 3996, which stipulated that contracts concluded with the private providers of goods and services in the context of the BOT model would be treated as private law contracts were later annulled by the Constitutional Court, which decided that such contracts should be treated as public service concession contracts. This has caused several problems. First, all concessions require the prior review of the Council of the State, which takes a long time. The second problem has to do with whether or not these contracts can include arbitration clauses. In fact Law 3996 states that 'the parties may agree to resolve disputes according to Turkish Law and in Turkey through arbitration'. However, it is commonly held that provisions in public contracts that call for arbitration are invalid in Turkish legislation. This is a serious problem since foreign investors who participate in BOT projects generally prefer arbitration as the main dispute-resolution mechanism. Third, the Council of the State refuses to confirm any contract stipulations on 'faults of the administration'. The remaining characteristics of the BOT model are as follows. According to the decision by the Council of Ministers specifying the implementation principles of Law 3996 (Official Gazette, 1 October 1994), the public agency in question needs to obtain the approval of the High Planning Council before concluding a BOT contract. When granting permission, the High Planning Council, together with the relevant public agency, specifies the required investment and the services to be rendered. The terms of the contract are specified in detail in the Decision on Implementation (Article 16). The maximum time period of a contract is 49 years. The contract has to specify the method that will be used to determine the prices of goods and services produced from the investment. The principles related to pricing are also detailed in the Decision on Implementation (Article 34). The contract may be terminated by the administration before it expires under certain circumstances, such as if the company fails to fulfil its liabilities, falls into financial difficulty or goes bankrupt. At the end of a contract period the investment and services are automatically taken over by the administration free of all liabilities and at no cost. The Treasury guarantees tax and duty exemptions, which are regulated in the Decision on Implementation (Articles 39-41).

There are several other problems with the current BOT system. The primary goals of any mechanism designed to attract and regulate private participation in the provision of infrastructure should include ensuring efficiency in the provision of goods and services, allowing and promoting competition whenever necessary, maintaining transparency and accountability, and securing a credible environment whereby the investor can expect a competitive rate of return. The legislation (Laws 3096, 3465, 3996) regulating the BOT model in the areas of electricity, highways and so on does not include any principle concerning the selection of private enterprises. Although various 
principles are outlined in the regulations and decisions of the Council of Ministers, most are extremely flexible and give the administration excessive discretion, with very limited accountability.

In addition, promoting competition is not regarded as a priority even in sectors where competition is possible. This is a simple consequence of a deeper problem with private sector participation in infrastructure. Recent international experience with the privatisation and regulation of utilities shows the importance of promoting competition and at the same time fostering investor confident through government regulation. There are various institutional approaches to achieving these goals, ${ }^{41}$ but Turkey still lacks a general regulatory framework for ground rules in all sectors. Individual cases are handled on an ad hoc basis, hence the excessive discretionary powers of the government. While discouraging competition, the current system also increases the risks associated with projects. There is a general concern that, to hedge against these risks, investors may require too many concessions, for example in terms of pricing and guarantees.

\section{Price regulations}

The prices of certain goods and services are directly specified by the state. However, the number of such goods and services declined after 1980. Although certain pieces of legislation authorising the state in this matter are still in effect, they are not implemented.

Price regulations are generally related to the goods and services provided by state enterprises. According to Decree Law 233, the Council of Ministers may intervene in the process of price determination (Article 35) and state economic enterprises may be odered by the Council of Ministers to carry out certain functions (or 'duties') in their areas of operation. In such cases, any losses incurred or profits foregone by the enterprises ('duty losses') are financed by the Treasury. This practice is most widely used in connection with agricultural subsidies. For instance, the State Agency for Purchasing Cereal Grains is responsible for support purchasing of cereal grains (wheat, barley, rye, oats, corn), the Turkish Sugar Factories Corporation for support purchasing of sunflowers, soybeans and sugar beet (Decree Law 233 and Article 8 of Law 6747), the Union of Agricultural Sales Cooperatives for purchasing mohair and wool (Article 27 of Law 3186) and the General Directorate of Monopolies for purchasing tobacco (Articles 1 and 2 of Law 196 and Article 17 of Law 3291). On the other hand the freight of the State Railways and Maritime Lines (Article 35 of Decree Law 233) and petroleum products (Article 5 of Law 5) are specified by the Council of Ministers, and the consumer price of natural gas (Articles 2 and 10 of Law 3154) by the Ministry of Energy and Natural Resources. Furthermore the prices of the goods and services produced by establishments sold or to be sold through revenue sharing certificates are specified by the High Planning Council (Article 6 of Law 2983, as amended by Law 4046). The Ministry of Health is entitled to regulate the prices of pharmaceuticals, for 
instance the ministry can restrict the net profits of pharmaceutical producers to 15 per cent of net sales revenues, and promotion expenditure to 5 per cent of net annual sales revenues (Official Gazette, 1 September 1995). The Municipalities Law 1580 (Articles 15/3, 43, 83), the Law on the Administration of Metropolitan Municipalities 3030 (Article 7) and the Local Administration Law 3360 (Article 144/14) authorise local administrations to determine the prices of various goods and services. The prices of some products produced by traders and industrialists are determined by chambers of small traders and craftsmen, under the Law on Small Traders and Craftsmen. Recent regulations stipulate that prices so specified must indicate the maximum levels. It is impossible for the board of directors of the chambers to refrain from price fixing, or set prices freely. Hence, for these products and services, the law sanctions collusive behaviour among suppliers. Finally, the minimum wage determined under Labour Law 1475, is implemented through an employment contract.

\subsection{State economic enterprises and privatisation}

State economic enterprises (SEEs) are regulated Decree Law 233, enacted at the beginning of the 1980s. The decree separates SEEs into two groups: public economic enterprises and public economic organisations. The capital of both is entirely owned by the state. Public economic enterprises are supposed to operate in accordance with commercial principles, while public economic organisations are monopolies or provide basic goods and services.

SEEs are established by the decision of the Council of Ministers. They are public legal entities but operate under private laws, except those regulated by Decree Law 233. They are not governed by the General Accounting Law and the State Bidding Law. The Decree Law 233 stipulates that SEEs should 'be administered autonomously and in compliance with economic principles'. The objectives of public economic enterprises are to contribute to capital accumulation and thus to generate further resources for investment 'by operating in accordance to economic requirements and in the direction of the principles of productivity and profitability'. Public economic organisations should carry out the functions and public services entrusted to them in accordance with economic and social requirements and in the direction of the productivity and profitability principles' (Article $2 / \mathrm{b}$ and c).

The practical implications of this emphasis on productivity and profitability are very limited. The Constitutional Court has ruled that the SEEs should operate according to the principles of productivity and profitability just like private enterprises, and behave in their external relations according to commercial principles and methods (Decision E.994/70-K. 994/65-2, 22 December 1994). The Constitutional Court has also decided that 'associated corporations' ${ }^{\prime 2}$ with the status of joint stock companies have different 'objectives of establishment, legal status and capital contributions' 
from private joint stock companies, and that 'from the point of equality principle, it is impossible to consider as equal these two sectors, which have completely different characteristics and legal status' (Decision E.994/89K.995/10 15 February, 1995). The court has also ruled that SEE subsidiaries where SEEs are minority shareholders are also different from private law 'legal or real persons' despite the fact that they operate under the provisions of commercial law. Hence, regulating them with different rules from those applied to 'private legal or real persons' does not violate the principle of equality (Decision E.991/5-K.929/9 18 February 1992).

It is evident that the state uses SEEs to intervene in the economy for political objectives. Indeed, Decree Law 233, which describe the status of the SEEs, contains provisions that give the state this opportunity. According to Article 35 , 'enterprises, establishments and associated corporations are free to set the prices of the goods and services they produce'. However, if necessary, the prices of those goods and services may be set by the Council of Ministers. In such cases, if the prices set by the Council of Ministers are below cost the losses and forgone profits will be met from allowances set aside in the general budget. It is stated in the same article that enterprises, establishments and associated corporations may be entrusted to the Council of Ministers in their areas of operation and that any losses or forgone profits will be covered by the Treasury. With regard to public economic organisations, Decree Law no 233 authorises the Co-ordination Council (High Planning Council) to adjust prices in order to increase social benefits. These provisions give the Council of Ministers the opportunity to intervene in the operations of the SEEs. The SEEs' annual schedules of general investment and finance are drawn up by the Council of Ministers. Small-scale completion investments may be undertaken with the approval of the related ministry provided that such investments are financed with the SEEs' own resources.

Turkey's privatisation effort started in 1986. However, the absence of a sound legal basis made progress very difficult. Earlier privatisation was generally undertaken at the discretion of the High Planning Council and Public Participation Administration, but some of their decisions to privatise were revoked by the judicial authorities because the administration occasionally engaged in practices that violated the rules (as was the case with a block sale of five cement factories to foreigners). Authorisation Law 3987 was subsequently put into force to regulate privatisation activities through decree laws. However, the Constitutional Court abolished Law 3987 on the ground that privatisation should be regulated by full laws. Law 4046 on arrangements for the implementation of privatisation was enacted in 1994.

In addition to this general legal coverage of privatisation, special legal arrangements were attempted for the privatisation of the electricity and telephone services. Unsuccessful attempts were made to privatise the Turkish Electricity Authority through Decree Law 513 and then Law 3974, both of which were rescinded by the Constitutional Court. As for privatisation of the 
PTT's telephone services, Decree Law 509 was enacted to this end but was later annulled by the Constitutional Court. Then the Law 400 was put into force, but this too was annulled. The same thing happened after the passage of Law 4107. In the summer of 1996 another attempt was made with Law 4165, which again was challenged by appeal to the Constitutional Court, but this time the challenge failed, possibly at last clearing the way for the privatisation of this industry. ${ }^{43}$

Although the privatisation schedule seems to be given a legal framework by Law 4046, the existence of certain shortcomings - such as the valuation of enterprises to be privatised - cannot be denied. Following public criticism of certain valuation decisions (such as the sale of Meat and Fish Products Co. to a meat and fish joint venture) the sales were withdrawn.

Since 1985, 127 enterprises have been earmarked for privatisation, seven of which were later excluded. All public shares in 73 of the remaining 120 enterprises were taken over by the private sector through block sales, public offerings and sales of shares on the Istanbul Stock Exchange. Now there are 47 enterprises in the privatisation portfolio, the public share in 26 of which is over 50 per cent. During the period 1986-94, \$2.09 billion revenues was secured from privatisation. (Privatisation expenditure amounted to $\$ 2.58$ billion in the same period.)

\section{Characteristics of the system launched by Law 4046}

Privatisation Law 4046 defines two main categories of privatisation: privatisation through the transfer of property and privatisation via alternative methods.

\section{Privatisation through the transfer of property}

Privatisation through the transfer of property relates to the sale of:

- Public economic enterprises and their establishments, associated corporations, assets and public shares in their subsidiaries.

- Public shares in commercial establishments of which the state owns more than 50 per cent of the capital, together with their establishments, associated corporations, assets and public shares in their subsidiaries.

- Public and Treasury shares in state subsidiaries.

- Assets of the general and annexed budgeted administrations and establishments with revolving capital, and public economic organisations that are not directly related to the public services they provide, together with their shares in subsidiaries.

Under the terms of Article 18/A-a of Law 4046, sales should be realised by partially or wholly transferring the production units and other property of the enterprises for an agreed consideration, or by partially or wholly transferring the share of the enterprises through internal and external block sales, block sales including deferred public offering, sales to employees, sales on the stock 
exchange and sales to security investment funds and/or security investment partnerships.

\section{Privatisation via alternative methods}

This relates to the privatisation of the manufacturing and service units of the general and annexed budgeted administrations and their subsidiary establishments with revolving capital (dams, highways, hospitals), and the goods and service units of state economic organisations (railways, airport organisations, tobacco, salt, alcohol, the Turkish Postal Organisation and the Turkish Telecommunication Organisation), through the granting of operational rights, leases or similar means. The details of the procedures are laid down in Article 18/A-b, c, d and e of Law 4046.

State-owned banks (excluding the central bank, Ziraat Bank, Halk Bank and Eximbank) were to be privatised before all else (Article 2/f) and the restructuring of the banks was scheduled to be completed within two years of the entry into force of the law (Provisional Article 3). The privatisation of commercial enterprises attached to local administrations and municipalities (called 'municipality economic enterprises') and their shares in all subsidiaries, regardless of the ratios, is conducted by bodies authorised by these administrations. The local administrations and their associations have to obtain the approval of the Council of Ministers to establish commercial organisations and to participate in established or planned enterprises (Articles 1/e and 26).

\section{The privatisation procedure}

It is the Privatisation High Council that decides whether to include organisations in the scope of privatisation. Companies opting for privatisation are required to make financial and legal preparations before a submitting their applications. Privatisation is undertaken by means of sales, leases, the granting of operating rights, the establishment of a property right other than ownership and profit sharing. The Council is empowered to order privatisation applicants to reduce, terminate or temporarily halt their activities if deemed necessary.

Organisations which are included in the privatisation schedule are considered as having transferred to the Privatisation Administration at no cost. Since they are now governed by private law, the provisions of Decree Law 233 and of the articles of incorporation contradictory to Law 4046, are not applicable to them. The articles of incorporation of enterprises that are joint stock companies are amended, and those that are not joint stock companies are changed to joint stock companies by the Privatisation Administration. Those that are changed to joint stock companies are not required to fulfil the requirements for formation of companies under the Commercial Code, Capital Market Law and other relevant laws while they remain in the privatisation programme. 
In the event of the public share falling below 50 per cent in organisations that are considered strategically important in terms of possible monopolisation and the protection of national interests, the Privatisation High Council is empowered to allot preferential shares, allowing the state influential voting rights in the general assembly (Article 13). The law necessitates the establishment of preferential shares amounting to more than 49 per cent in the case of certain organisations (Turkish Airlines, Ziraat Bank, the Turkish Petroleum Organisation and so on). Law 4046 also empowers the Ministry of Industry and Commerce to prevent mergers that could lead to monopolisation and the distortion of competition.

\subsection{Conclusion}

The essential components of a legal framework for a private-sector-oriented economy have been in existence for quite some time in Turkey, although there is some ambiguity about the extent to which property rights are protected from arbitrary action by the state. Nevertheless, one can safely argue that market-oriented rules regulating property rights, contracts and company governance have become well embedded in economic and social life. This chapter has argued that, if Turkey is to complete its transition from a protected and clientelistic economy to one in which competition has prominence in the allocation and use of resources, then a significant effort is necessary to enforce competition law, promote a more competitive code of business conduct, provide a legal framework to regulate the participation of the private sector in infrastructural provisions and enhance the transparency and competitiveness of government procurement.

\section{Notes}

1. Non-attenuated property rights are defined as rights that are exclusive, transferable and enforceable. In the non-attenuated case Pareto-efficient outcomes prevail in a market economy (Mercuro and Ryan, 1984, pp. 24-5).

2. Mercuro (1989), p. 14.

3. The appropriate mix of the private, status and communal rights is discussed in Commons (1957), Williamson (1985) and North (1990). See also Barzel (1989) on related discussion of property rights.

4. Cooter and Ulen (1988), p. 90.

5. See Cin (1987) pp. 365-70 for an English summary of the historical developments in the Turkish land regime, starting with the Ottoman times.

6. For details see Devlet Planlama Teşkilati (1995).

7. Article 44: 'The state shall take necessary measures to maintain and improve the productive use of land, to provide land for farmers with insufficient land of their own, or no land.

Distribution of land to farmers with no or insufficient land shall not lead to a fall in production, or to the depletion of forests and other natural resources. 
Land distributed for this purpose may not be divided or transferred to others, except by inheritance, and shall be used only by farmers, benefiting from distribution and their inheritors.

The rules according to which land is to be returned to the state upon the disappearance of these conditions will be stated by law.

8. Law 3083 is about land arrangements in irrigatable areas.

9. Article 168: 'Natural wealth and resources shall be under the jurisdiction and at the disposal of the State. The right to explore and to exploit these resources belongs to the State. This right of the State may be delegated to real persons and corporate bodies for certain periods. Carrying out exploration and exploitation activities by the State in conjunction with real persons and corporate bodies, or directly by them, is dependent on the explicit authorization of the law. The procedures and rules of supervision and inspection by the state as well as sanctions shall be defined by law.'

10. Article 43: 'The coasts are under the sovereignty of the State and subject to the disposal of the State.

Public interest shall have priority in the utilization of the sea coast, lake shores or river-banks, and of the coastal strip along the sea and lakes.

The width of the coastal strip shall be stipulated by law according to the aims of utilization and permission, and conditions for utilization by individuals.

Article 169: 'All forests are under the care and supervision of the State.'

11. 'In terms of real estate, the right of property is the right of usage within the limits of the permission granted by the State (Decision E.988/34-K.989/26 of 21 June 1989.

12. According to the Code of Obligations, eviction is possible and easy. However, Law 6570, Article 7 places some restrictions on eviction in municipalities and some other special regions, where the supply of houses is thought to be restricted.

13. Article 35: 'Everyone is entitled to the rights to property and inheritance. These rights may be limited by law only in the public interest. The exercise of the right to property shall not be in contravention to the public interest.'

14. Article 46: 'The State and public corporate bodies shall have the power to expropriate and to exercise eminent domain on all or part of private real estate for sake of public interest, according to principles and procedures prescribed by law, and on condition that compensation is paid in advance.

The form and procedure for determining the amount of compensation shall be prescribed by law. In determining the amount of compensation, the law shall take into account current value established by official appraisals, unit prices and construction costs for real estate, and similar objective criteria. The law shall stipulate the mode of tax assessment arising out of any difference between the amount of compensation and the declared value.

Compensation for expropriation shall be paid in cash and in advance. However, the law shall prescribe the procedures for payment of compensation in cases where land is expropriated for the implementation of land reform, or for major power, irrigation and resettlement projects, reforestation, protection of the coast, and tourism. In cases where the law allows payment in installments, the period of payment may not exceed five years; payment shall be made in equal installments at an interest rate equivalent to the highest interest paid on the public debt.

Compensation for land expropriated from the small farmer who cultivates his own land shall be paid in advance, in any case.' 
15. Article 47: 'A private enterprise performing public service may be nationalized when it is required by the exigencies of public interest.

Nationalization shall be compensated at real value. The form and procedures for the determination of real value shall be prescribed by law.'

16. 4th Law Department of the Supreme Court of Appeals, Decision no. E.985/398K.985/5074 of 20 May 1985. YKD vol. xi, no. 10. p. 1454; Council of State, Decision no. E. 981/4-K.981/25 of 13 April 1981, Dannștay Dergisi, nos 44-5, p. 60.

17. Articles 131, 176, 177, 202, 370, 378, 379, 385, 387, 390, 392, 516, 517, 537.

18. Article 18 of the Cadastre Law.

19. Article 82 of the Execution and Bankruptcy Law.

20. Decision E. 992/13-K. 992/50 of 20 October 1992.

21. The Decree Law 233, Article 57.

22. Cooter and Ulen (1988), pp. 214-23.

23. Ibid., pp. 223-226.

24. See Schwartz (1992) and Cooter and Ulen (1988) for a detailed discussion of incomplete (imperfect) contracts.

25. See Ostas and Lee (1995) for a theoretical discussion and Hungarian Contract Law.

26. Article 48: 'Everyone has the right to freedom of work and contract in the field of his/her choice. The establishment of private enterprises is free.'

27. For the housing rental market and the labour market, Laws 6570 and 1475 respectively impose restrictions on free contracting with the purpose of protecting and helping the tenant and the worker.

28. Article 5 of the Law on Protecting Consumer Rights 4077.

29. Code of Obligations, Article 483.

30. Commercial code 1263.

31. Civil code, Article 765.

32. This chapter will not examine this problem in detail. We may point out, however, that while the average duration of cases in collection courts is relatively short (110 days in 1991), it is longer in commercial courts (233 days) and cases related to real estate registration (654 days).

33. For details see Posner (1992, ch. 14); Tirole (1991); Black et al. (1996).

34. Article 48. 'Everyone has the right to freedom of work and contract in the field of his/her choice. The establishment of private enterprises is free.

The State shall take the necessary measures to ensure the functioning of private enterprise in accordance with the requirements and social aims of the national economy and of security and stability.'

35. Black et al. (1996) envisage a tighter constraint on interested transactions by requiring that such transactions should obtain the approval of non-interested members of the board of directors. Such is not the case in Turkey.

36. These provisions are quite similar to those in Hungarian company Law. See Gray et al. (1992), p. 25.

37. An example is the Bankruptcy Prevention Act (1984) of France. See Atiyas (1995) and Biais and Malewt (1996) for a discussion.

38. See Chapter 12 of this volume for Turkish competition law.

39. A recent example of this cultural confusion took place when demand for poultry products increased in response to fear that beef could be infected by 'mad-cow' disease. The poultry industry was accused by the press of exploiting the increase in demand by charging exorbitant prices. The industry responded to the accusation by publishing full-page newspaper ads to inform the readers that the industry was actually collectively imposing price ceilings. 
40. See Chapter 11 of this volume.

41. See for example Spiller (1995).

42. Associated corporations are joint stock companies whose equity capital is more than 50 per cent owned by SEEs.

43. Only one statement in the law was annulled by the Constitutional Court.

\section{References}

Atiyas, I. (1995) 'Bankruptcy Policy', in C. Frischtak (ed.), Regulatory Policies and Reform: A Comparative Perspective (Washington, DC: Private Sector Development Department, World Bank).

Barzel, Y. (1989) Economic Analysis of Property Rights (Cambridge: Cambridge University Press).

Biais, B. and J. F. Malewt (1996) 'Incentives and Efficiency in the Bankruptcy Process: The Case of France', PSD Occasional Paper No. 23 (Washington, DC: World Bank).

Black, B., R. Kraakman and J. Hay (1996) 'Corporate Law from Scratch', in C.W. Gray and A. Rapaczynski (eds) Corporate Governance in Central Europe and Russia, Vol. 2 Insiders and the State. (Budapest: Central European Press). pp. 245-302.

Buğra, Ayşe (1994) State and Business in Modern Turkey (New York: State University of New York Press).

Cin, H. (1987) Miri Arazi ve Bu Arazinin Özel Mülkiyete Dönüşümü (Ottoman Public Land and its Transformation to Private Property, in Turkish, with English summary) (Konya: Selçuk Üniversitesi Basımevi).

Commons, J. R. (1957) Legal Foundations of Capitalism (Madison: University of Wisconsin Press).

Cooter, R. and T. Ulen (1988) Law and Economics, (London HarperCollins).

Devlet Planlama Teşkilati (1995) Harita Tapu ve Kadastro Özel Ihtisas Komisyonu Raporu (State Planning Organization Report of the Commission on Maps and Cadastre), (Ankara, Turkey: State Planning Organisation).

Gray, C. W., R. J. Hanson and M. Heller (1992) 'Legal Reform for Hungary's Private Sector,' Policy Research Working Paper (WPS 983) (Washington, DC: World Bank).

Mercuro, N. (1989) 'Towards a Comparative Institutional Approach to the Study of Law and Economics', in N. Mercuro (ed.), Law and Economics, (Dordrecht, Netherlands: Kluwer Academic Publishers).

Mercuro, N. and T. P. Ryan (1984) Law, Economics and Public Policy (Greenwich, Conn.: JAI Press).

North, D. C. (1990) Institutions, Institutional Change and Economic Performance (Cambridge: Cambridge University Press).

Ostas, D. T. and B. A. Lee (1995) 'Economic Analysis of Law as a Guide to PostCommunist Legal Reforms: The Case of Hungarian Contract Law', American Business Law Journal, vol. 32, pp. 355-98 (Also appeared as IRIS Reprint no. 62, University of Maryland).

Posner, R. A. (1992) Economic Analysis of Law, 4th edn (Boston, Mass: Little, Brown).

Schwartz, A. (1992) 'Legal Contract Theories and Incomplete Contracts', in L. Werin and H. Wijkander (eds), Contract Economics (Oxford: Blackwell), pp. 76-108.

Spiller, P. (1995) 'Regulatory Commitment and Utilities' Privatization', in J. S. Banks and E. A. Hanusek (eds), Modern Political Economy (New York and Cambridge: Cambridge University Press). 
Tirole, J. (1991) 'Ownership and Incentives in a Transition Economy,' Institute for Policy Reform Working Paper 31 (Washington, DC: IPR).

Togan, S. (1997) 'Opening up the Turkish Economy and the European Economies in Transition', this volume.

Williamson, O. E. (1985) The Economic Institutions of Capitalism (New York: Free Press). 